\title{
Exceptional involvement of medulla oblongata in Wilson disease
}

Aurélia Poujois, MD, PhD, Antoine Guillonnet, MD, and France Woimant, MD

Neurology ${ }^{\circledR}$ 2019;92:770-771. doi:10.1212/WNL.0000000000007321

Figure 1 Brain magnetic resonance sagittal T2-weighted fluid-attenuated inversion recovery (FLAIR) image demonstrates hyperintensity in the medulla oblongata and the mesencephalon

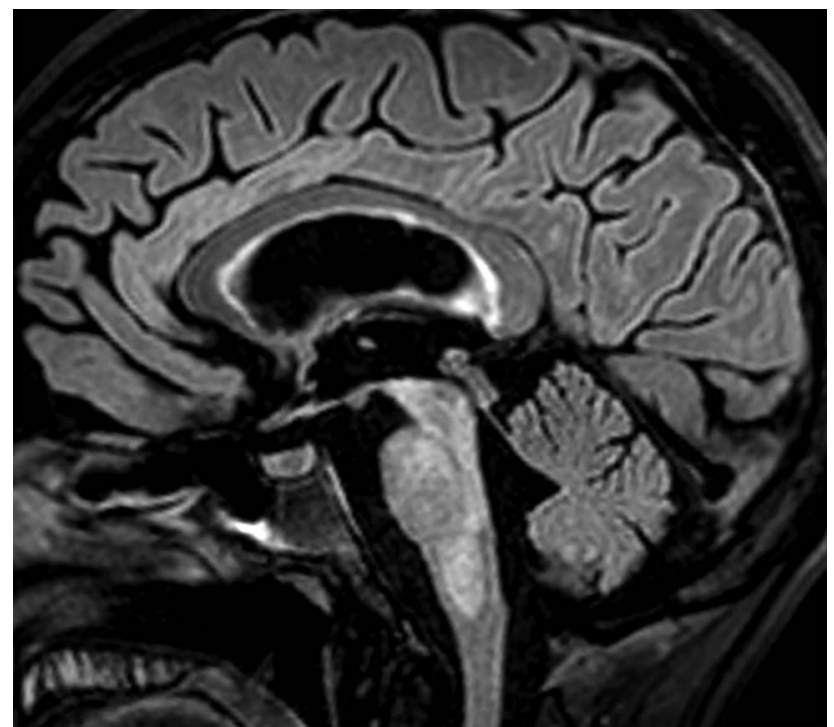

A 19-year-old man presented with a 1.5-month history of hypokinetic dysarthria, slight hypokinesia, and micrographia. Brain MRI showed fluid-attenuated inversion recovery (FLAIR) (figure 1) and T2 (figure 2) hyperintensities in the medulla oblongata and the mesencephalon. Copper tests reported high 24-hour urinary copper excretion, low serum copper, low ceruloplasmin, and high exchangeable copper. Kayser-Fleischer rings were present. ATP7B genetic analysis confirmed the diagnosis of Wilson disease (WD) with the presence of 2 mutations.

Brain MRI of patients with WD with neurologic phenotype commonly displays T2 or FLAIR bilateral hypersignal in the basal ganglia, mainly the putamen. ${ }^{1,2}$ Medulla oblongata involvement is exceptional and should not challenge the diagnosis of WD.

\section{Disclosure}

The authors report no disclosures relevant to the manuscript. Go to Neurology.org/ $\mathrm{N}$ for full disclosures.

\section{Study funding}

No targeted funding reported.

\author{
Correspondence \\ Dr. Poujois \\ aurelia.poujois@aphp.fr
}

From the Neurology Department (A.P., F.W.), National Reference Centre for Wilson's Disease (A.P., F.W.), and Neuroradiology Department (A.G.), AP-HP, Lariboisière University Hospital, Paris, France.

Go to Neurology.org/N for full disclosures. 
Figure 2 Brain magnetic resonance axial T2-weighted image shows symmetric hyperintensity in the medulla oblongata

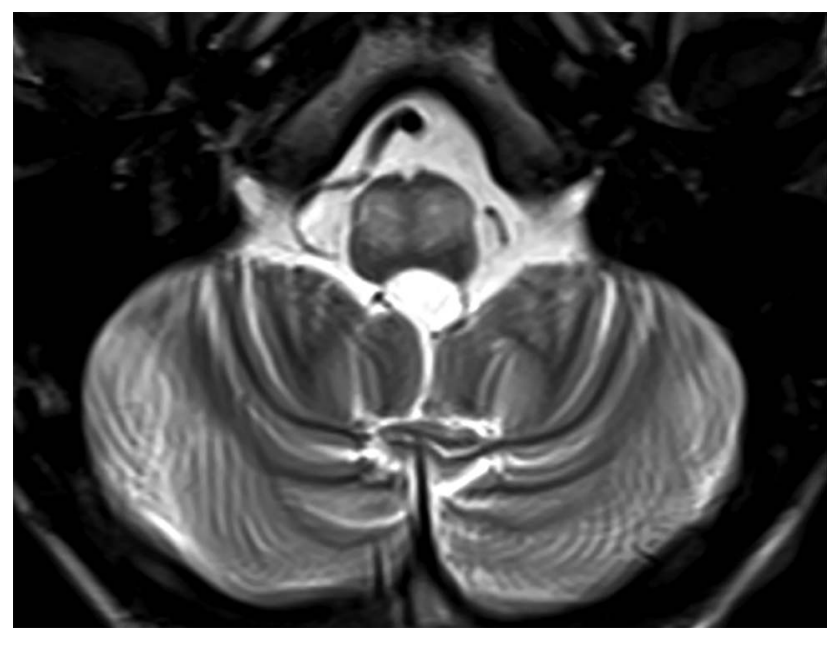

Appendix Authors

\begin{tabular}{|c|c|c|c|}
\hline Name & Location & Role & Contribution \\
\hline $\begin{array}{l}\text { Aurélia } \\
\text { Poujois, } \\
\text { MD, PhD }\end{array}$ & $\begin{array}{l}\text { Neurology } \\
\text { Department and } \\
\text { National Reference } \\
\text { Centre for Wilson's } \\
\text { Disease, AP-HP, } \\
\text { Lariboisière } \\
\text { University Hospital, } \\
\text { Paris, France }\end{array}$ & Author & $\begin{array}{l}\text { Concept and study } \\
\text { design, interpretation } \\
\text { of data, drafting the } \\
\text { manuscript }\end{array}$ \\
\hline $\begin{array}{l}\text { Antoine } \\
\text { Guillonnet, } \\
\text { MD }\end{array}$ & $\begin{array}{l}\text { Neuroradiology } \\
\text { Department, AP-HP, } \\
\text { Lariboisière } \\
\text { University Hospital, } \\
\text { Paris, France }\end{array}$ & Author & $\begin{array}{l}\text { Acquisition and } \\
\text { interpretation of } \\
\text { radiologic data, } \\
\text { revising the } \\
\text { manuscript for } \\
\text { intellectual content }\end{array}$ \\
\hline $\begin{array}{l}\text { France } \\
\text { Woimant, } \\
\text { MD }\end{array}$ & $\begin{array}{l}\text { Neurology } \\
\text { Department and } \\
\text { National Reference } \\
\text { Centre for Wilson's } \\
\text { Disease, AP-HP, } \\
\text { Lariboisière } \\
\text { University Hospital, } \\
\text { Paris, France }\end{array}$ & Author & $\begin{array}{l}\text { Interpretation of data, } \\
\text { revising the } \\
\text { manuscript for } \\
\text { intellectual content }\end{array}$ \\
\hline
\end{tabular}

\section{References}

1. Sinha S, Taly AB, Ravishankar S, et al. Wilson's disease: cranial MRI observations and clinical correlation. Neuroradiology 2006;48:613-621.

2. Zhong W, Huang Z, Tang X. A study of brain MRI characteristics and clinical features in 76 cases of Wilson's disease. J Clin Neurosci 2019;59:167-174.

\section{Subspecialty Alerts by E-mail!}

Customize your online journal experience by signing up for e-mail alerts related to your subspecialty or area of interest. Access this free service by clicking on the "My Alerts" link on the home page. An extensive list of subspecialties, methods, and study design choices will be available for you to choose from-allowing you priority alerts to cutting-edge research in your field! 


\title{
Neurology
}

\section{Exceptional involvement of medulla oblongata in Wilson disease \\ Aurélia Poujois, Antoine Guillonnet and France Woimant \\ Neurology 2019;92;770-771 \\ DOI 10.1212/WNL.0000000000007321}

\section{This information is current as of April 15, 2019}

\author{
Updated Information \& \\ Services \\ including high resolution figures, can be found at: \\ http://n.neurology.org/content/92/16/770.full \\ References \\ This article cites 2 articles, 0 of which you can access for free at: \\ http://n.neurology.org/content/92/16/770.full\#ref-list-1 \\ Subspecialty Collections \\ This article, along with others on similar topics, appears in the \\ following collection(s): \\ Basal ganglia \\ http://n.neurology.org/cgi/collection/basal_ganglia \\ MRI \\ http://n.neurology.org/cgi/collection/mri \\ Parkinson's disease/Parkinsonism \\ http://n.neurology.org/cgi/collection/parkinsons_disease_parkinsonism \\ Permissions \& Licensing \\ Information about reproducing this article in parts (figures,tables) or in \\ its entirety can be found online at: \\ http://www.neurology.org/about/about_the_journal\#permissions \\ Reprints \\ Information about ordering reprints can be found online: \\ http://n.neurology.org/subscribers/advertise
}

Neurology ${ }^{\circledR}$ is the official journal of the American Academy of Neurology. Published continuously since 1951, it is now a weekly with 48 issues per year. Copyright (O 2019 American Academy of Neurology. All rights reserved. Print ISSN: 0028-3878. Online ISSN: 1526-632X.

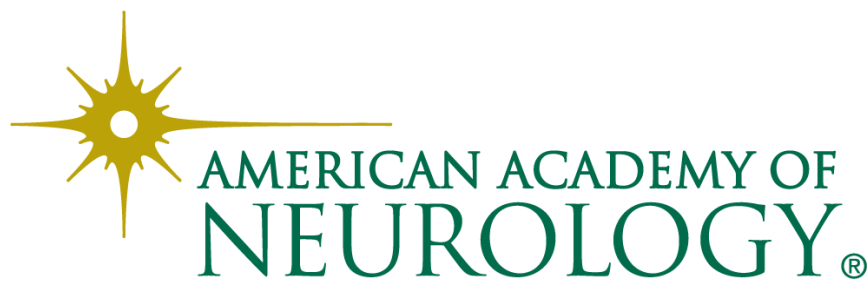

